\title{
Accounting for a Riot: Religious Identity, Denying One's Prejudice, and the Tool of Blasphemy
}

\author{
Idhamsyah Eka Putra ${ }^{\text {ab }}$, Wolfgang Wagner ${ }^{\mathrm{c}}$, Peter Holtz ${ }^{\mathrm{d}}$, Any Rufaedah ${ }^{\text {be }}$ \\ [a] Faculty of Psychology, Persada Indonesia University, Fakarta, Indonesia. [b] Division for Applied Social Psychology Research (DASPR), Jakarta, Indonesia. \\ [c] Institute of Psychology, University of Tartu, Tartu, Estonia. [d] Knowledge Construction Lab., Leibniz-Institut für Wissensmedien (Knowledge Media Research \\ Center), Tübingen, Germany. [e] Department of Psychology, Universitas Nahdlatul Ulama Indonesia, fakarta, Indonesia.
}

Journal of Social and Political Psychology, 2021, Vol. 9(1), 69-85, https://doi.org/10.5964/jspp.5565

Received: 2018-06-01 • Accepted: 2020-12-04 • Published (VoR): 2021-02-19

Handling Editor: Debra Gray, University of Winchester, Winchester, United Kingdom

Corresponding Author: Idhamsyah Eka Putra, Universitas Persada Indonesa, Jl. Diponegoro No. 74 Jakarta Pusat, Indonesia. E-mail: idhamsyah.eka@upiyai.ac.id

\begin{abstract}
This paper presents an analysis of interviews of participants in a political manifestation in Indonesia about the reasons for the rally and the resulting riot. The rally was held in the middle of the Jakarta gubernatorial election, against a non-Muslim incumbent who was accused of having insulted the Quran. We argue that there is a deep relationship between social identities and religion, which has implications for societal togetherness and political freedom. Using a snowball technique, we interviewed 16 Muslims who had participated in this rally. The findings suggest that 1) even though the rally was held in the middle of an election, the demonstrators denied that the rally was politically motivated; 2) Those demonstrators who thought that intruders had infiltrated the rally, maintained that the intruders are to be held responsible for any violence, but not the 'actual' participants. 3) Interviewees claimed that their actions were not motivated by anti-Chinese prejudice, although traces of racist thinking can be found in their statements. The findings are discussed before the background of social representations, social identity, theories of collective action, and the black sheep effect.
\end{abstract}

\section{Keywords}

collective action, crowd behaviour, riots, religious identity, racism, blasphemy, Indonesian politics

In most social groups, there are values that are considered sacred (Sheikh, Ginges, Coman, \& Atran, 2012). That is, "a thing (such as a piece of land), or an idea (such as a national right) is not an ordinary preference that can be valued along a metric common with economic goods" (Ginges \& Atran, 2014, p. 274). In monotheistic religions, for example, adherents base their religious beliefs on a holy book, which is often considered to be beyond criticism. Strong believers or endorsers of a religion will consider any criticism as an insult or an act of blasphemy.

In democratic societies, the freedom of speech is protected by the law unless statements constitute a personal insult (for example, in the form of hate speech). In the political arena however, the use of black campaigning is not unusual, that is, the use of any means to vilify, embarrass, or to mock the political opponent (van Dijk, 1992). To camouflage hatred toward a political opponent because of his religious or ethnic background, prejudiced individuals will often produce socially acceptable answers to avoid moral sanctions. In Western societies, for example, the right to freedom of speech can be used as a strategy to escape the accusation of spreading hate speech (see Pettersson, 2019; White \& Crandall, 2017).

Uniquely in Indonesia, a democratic country with Muslims as the majority, a lenient critique expressed from minority to majority could be deemed as an insult or a blasphemy in which it might result in protests and collective action 
to punish the blasphemer. One such event happened during the political electoral campaigns (2016-)2017 for the Jakarta governor. There were a series of Muslim protests during the 2017 Jakarta elections accusing the Chinese-Christian incumbent of having insulted Islam. At one point, a protest rally against the alleged blasphemy became violent. In the present study we interview participants in these events to gain insights in 1) the role and function of blasphemy accusations in the political arena as a face saving strategy to deny one's racist prejudice and 2) the construction of a positive collective self-image in spite of despicable acts by ingroup members.

We will first present the Indonesian background and the socio-historical development of the events and then outline our theoretical frame that comprises religion, social representations, and social identity, masking racism, and justifying non-normative collective action.

\section{Socio-Historical Background}

\section{Islam and Ethnic Groups in Indonesia}

The Indonesian archipelago consists of five large islands and thousands of smaller islands, which are populated by indigenous people who together represent the majority of the population. Because Islam is the largest religion, Muslim-indigenous groups tend to dominate and stand out in political and cultural life. Ethnic Chinese are considered a non-native Indonesian group, an attribute that is reserved for the Chinese and not for ethnicities like Indians or Arabs. The reason lies in their preserved traditions and language, which differ from other ethnic groups in Indonesia. More often, the name "Chinese" refers to Chinese non-Muslims, a label that is not used for Chinese who are Muslims (Putra, 2016). Chinese have suffered from social exclusions and hate crimes that occurred in almost all of Indonesia's provinces (Betrand, 2004).

In 2001, Abdurrahman Wahid, the 4th President of Indonesia, removed the discriminating policies limiting the Chinese tradition and the label of 'second class citizen' in identity cards (Putra, 2016). Since then, Chinese Indonesians can engage in politics and run for office. Nonetheless, as the Chinese have been denigrated for many years, Chinese candidates still face tough challenges from indigenous Muslims.

\section{Politics in Indonesia and the Events Around the 2017 Jakarta Election}

In Indonesia, there have been ups and downs of religious movements involved in politics (Hosen, 2005). During the process of nation-building, Indonesia had a debate of whether or not Indonesia should make Islam its state ideology (Steenbrink, 1999). This idea was proposed by Islamic groups that had actively been involved in Indonesia's independence endeavors. These groups argued that Islam should be the sole foundation for the state since Islam was superior over other ideologies and Indonesia was the world's largest Muslim population. Secular groups (i.e., typically Muslims moderates and non-Muslims), opposed this ideology (Effendy, 2003).

During Soeharto's era from 1966 to 1998, religious political ideology was suppressed and up until now, communism was banned. However, after 1998 religious conservatism has been resurging and playing a key role in political constellations. For instance, the last two Jakarta' elections have witnessed how religion is used in politics (Lamb, 2017; Putra, 2016).

Jakarta is the capital city of Indonesia, where Muslims $(\approx 85 \%)$ are the majority followed by Christians $(\approx 10 \%)$. In early 2017, Jakarta held its third direct gubernatorial election. Although the Christian Chinese Basuki Thahaja Purnama (BTP, nicknamed Ahok, which will be used in the following) was the incumbent, this was the first time for him to also run for governor: In 2012, he had joined Jakarta's government as deputy of governor Joko Widodo; in 2014 he replaced Joko Widodo as governor when Widodo was elected president of Indonesia. Since Ahok's first involvement in politics, Muslims rejected him as Chinese and Christian and as being potentially harmful for the Muslim majority, which is another word for their racial prejudice (for details see Putra, 2016).

From October 2016 to the end of March 2017, there were at least five Muslim rallies who opposed Ahok's participation in the 2017 Jakarta gubernatorial election. Naturally, the organisers of these rallies rejected accusations of a hidden racist agenda. Instead they produced the accusation of Ahok having insulted Islam, which is a serious crime in Indonesia. Any critical mention of Muslim religious activity can result in an accusation of blasphemy. 
The focus of this paper's study is the November 4, 2016, rally, which was a reaction to a speech that Ahok had delivered during a work visit to Kepulauan Seribu Regency, north of mainland Jakarta, on September 27, 2016. Even though there were no direct complaints by Kepulauan Seribu citizens, a week after the actual speech Buni Yani, a university lecturer, uploaded a shortened and doctored version of a recording of the speech on his Facebook page, claiming that the governor had insulted a verse of the Quran. This stirred anger with internet users and eventually a series of rallies by hardline Muslim communities in Greater Jakarta were called for. This is a short version of Ahok's speech:

[...]. Don't believe what people say. It's possible, in your inner hearts you may feel that you cannot vote for me, because you have been tricked by [using]..$^{1}$ Al-Maidah verse $51^{2} \ldots$ [audience laughed], but it's your right. So if you feel like you cannot vote for me, because [you've been fooled and] you are afraid of being condemned to hell [because of what is stated in Al-Maidah: 51], well that's alright, because it's your personal calling. This program will continue. So you don't have to feel uneasy. Like in your conscience you feel like 'I cannot vote for Ahok, I don't like him... but if I accept the program, I feel bad.' If you feel bad you can slowly die from stroke [audience laughed]. ... So, let's say [....] it's your right as citizens of Jakarta. It just happens that I'm the governor with the program. So this has nothing to do with how you feel about who you want to vote for. That's all. [....]. (See also Batubara, 2016)

The resentment escalated on October 6th when some NGOs lead by Novel Bakmumin, a legal practitioner linked to Front Pembela Islam (FPI/ Islamic Defender Front), reported Ahok's speech to the police as being offensive towards Islam (Kholid, 2016). Ahok officially apologized for his speech on October 10 (Wijaya, 2016), but the plaintiffs did not withdraw their accusation. Moreover, on October 14, thousands of Muslims commanded by the FPI protested in front of the City Hall, demanding that Ahok must be persecuted (Kapoor \& Jensen, 2016). The leader of FPI, Rizieq Shihab, threatened to organize a larger rally in three weeks from that date, if the police did not comply with their demand.

As the legal process continued and the police still interrogated witnesses, a larger mass rally happened on November 4. This rally came to be known as "Defending Islam Action, Edition II" or "Defending Islam Action 411" (November 4th). Hundreds of thousands of Muslims from several areas in Java came to Jakarta to demand Ahok's persecution, and they completed a march to the Presidential Palace (BBC, 2016a). The masses also demanded to speak with President Joko Widodo, but the president was not available. After $18.00 \mathrm{~h}$, the rally ended with a violent conflict between protesters and the police. One protester died and several others as well as police officers were injured. Two days later, on November 16, Ahok was officially named as a suspect in the blasphemy case (BBC, 2016b), but he was still allowed to participate in the 2017 Jakarta gubernatorial election.

Disappointed by the delay of Ahok's trial on blasphemy, hundreds of thousands of Muslims once again staged a rally that was known as "Defending Islam Action 212" (Quiano \& Griffiths, 2016), on December 2. Unlike the previous 411 rally, this protest was peaceful. Nine days after this protest, Ahok had his first trial at the South Jakarta District Court. In the same week, Buni Yani, the uploader of the viral video, was named as suspect and charged because of sharing manipulated and hoax information.

After two more rallies on February 21 and March 31, and after several trials, Ahok was found guilty of blasphemy and sentenced to two years in jail on May 9, 2017 (Lamb, 2017). This was after having lost the gubernatorial election. Ahok then refused his right to appeal, announcing that his case had become politicized (Cochrane, 2017).

\section{Identity, Social Representations, and Religion}

Social identity is "that part of an individual's self concept which derives from his [or her] knowledge of his [or her] membership in a social group (or groups) together with the value and emotional significance attached to that

1) In the Buni Yani version, the word "using" is cut.

2) English version of Ahmadiyya verse 51: O you who have believed, do not take the Jews and the Christians as allies. They are [in fact] allies of one another. And whoever is an ally to them among you - then indeed, he is [one] of them. Indeed, Allah guides not the wrongdoing people. 
membership." (Tajfel, 1978, p. 63). This definition stands at the beginning of theorizing about social identity, but it does not tell us much about where the feelings of membership in a group and its emotional underpinnings come from.

Social representations (SRs) (Moscovici, 1961/2008) are notions "conceptually located across minds instead of within minds resembling a canopy across people's concerted talk and actions" and "they unite mental processes as well as behaviours and the social objects emerging thereof" (Wagner, 2017, p. 27). The specific social self-representations entertained by a group (Moscovici, 1988, 2008) and the group members' social identities are closely entwined in everyday social life.

The stock of SRs that persons maintains allows them to relate to others with either a very similar stock of SRs and also to those with a divergent stock of SRs. The contents of the background knowledge and SRs make up a person's identity and forms a configuration with a structure and a hierarchy (Breakwell, 2015). In this process it does not make sense to distinguish a personal from a social identity as both coincide and are involved in creating feelings of belonging to a family, a social group or a nation.

Hence, identity and a group's system of representations are crucially linked because if it were not so "we cannot explain why particular people have different perspectives, draw on particular representations, defend them in the ways they do, and why other representations are ignored or contested" (Howarth, 2014, p. 4.2-4.3). Taking this perspective seriously, researching representations of a certain social object and how it is constructed would mean to observe the content of the representations that is "being enacted by social actors through their situated discourse and other activity" (Wagner, Mecha, \& Carvalho, 2008, p. 38). Therefore, in the present study, how we analyse and understand the data connects strongly with social representation and identity theory.

It is important to see that identity is not only a cognitive condition but also a deeply emotional and affective state. Identities are dominant in shaping the strength of affiliation and the sense of belonging, which gives a feeling of security and support by other group members (e.g. Deaux, 1996) and it is here that sacred beliefs become important in feelings of identity (Wagner, 2020).

In Indonesia, the dominant Muslim religion widely determines the state's actions and institutions. Citizens socialised into countries such as Indonesia derive a salient part of their identity from religious belonging. Religious beliefs in their committed form are among the most affectively laden representations that can beset people. Identities derived from affectively charged representational systems like religions imply a particularly strong feeling of group attachment and preparedness for collective action. Consequently, politicians tend to exploit feelings of affiliation and preparedness for action for their own purposes (e.g., Sen \& Wagner, 2009).

Religious commitment is characterized by placing high value on religious symbolism and normative behaviour in everyday life. The consequent ubiquity of religious markers, either in material or behavioural form, keeps religious creed salient even in unsuspecting circumstances (Wright \& Young, 2017). People driven by religious identities tend to respond particularly angry to perceived violations of their sacred symbolism, called blasphemy, and violent responses to perceived injustices can frequently be seen in Muslim countries (Brown, Abernethy, Gorsuch, \& Dueck, 2010; Putra, Wagner, Rufaedah, \& Holtz, 2019).

Religious creed is especially prone to devalue and denigrate outsiders and meta-representations of the outgroup's beliefs frequently are grossly distorted. As the ingroup perceives any idea derived from a prophet's book as being beyond scrutiny, religions easily lend themselves to being abused for political reasons. Strict believers represent non-believers and particularly atheists as stripped of most human qualities, and deprived of humanness (Holtz \& Wagner, 2012; Leyens et al., 2000). This attribution of lesser human qualities can be seen as a kind of religious racism (Putra \& Wagner, 2017).

\section{Collective Actions and Riots}

Collective action can be formally normative, that is following established rules of expressing protest, or non-normative if it violates the culturally approved space of expression and turns to violence. In the former case demonstrators largely conform to the wider social consensus and is typical for people who may harbour a resentment about the issue at stake. The latter case, rioting, is related to contempt, which, unlike anger, entails psychological distancing and a lack of reconciliatory intentions (Tausch et al., 2011). In reality, there is no clear separation of normative and non-normative collective action and the normative may switch to rioting behaviours depending on the situation and the response of the 
opposing party, which very often is the police (Stott \& Reicher, 1998b; Tausch et al., 2011; van Zomeren, Spears, Fischer, \& Leach, 2004). Since the events during collective actions can change dramatically in a relatively short amount of time, demonstrators and other involved parties (e.g., the police) will often dynamically re-interpret the situation (Vestergren, Drury, \& Hammar Chiriac, 2019).

The more interesting aspects of crowd behaviour for the present research are identity related. It has been shown that the participants of heterogeneous groups that engage in a collective protest tend to develop a feeling of shared identity with the others that may not have been there before. The shared, mostly political goals and activities homogenize the participants depending on one hand on how they represent the ideas and actions of other participants, and of other groups in society (Batel \& Castro, 2015) and of how they see their participation as an expression of their social identity and how they get absorbed in its collective enactment (Drury \& Reicher, 2005). On the other hand, the experience of standing together against opposing outsiders such as the police contributes to homogenize the rioters' felt identity (Drury \& Reicher, 2000; Reicher, 1996). The dynamics of conflict during an initially peaceful rally leads to a new pattern of social relations among participants and redefines their self-categorization and with this their social identity (Stott \& Drury, 2000). In the case of radicalization, this identity change may go so far as to estrange the participants from their original ingroup and allies (Becker, Tausch, Spears, \& Christ, 2011).

Non-normative violent events during manifestations may come about by several reasons: There may be sub-groups of the protesters who plan to act violently, for example the 'Black Block' in European police parlance, there may be outsiders who provoke the demonstrators to respond violently, and there is the police that frequently does not have a very differentiated view of the protesters (Drury \& Reicher, 2000; Stott \& Reicher, 1998a). Clearly, for saving face and group reputation, there are only two factors that can convincingly justify non-normative action: Provocation either by the police or by civic opponents.

Maintaining an ingroup's positive self-image is a powerful motivation in group life (e.g. Zeromskyte \& Wagner, 2019) and the strategy of attributing non-normativity to external actors is one of the most frequently used ways to achieve this goal. However, we also see that if there is evidence showing identifiable members of the ingroup as culprits, the group may respond by ostracising them and by playing out the so-called 'Black Sheep' method (Marques \& Paez, 1994; Yzerbyt, Leyens, \& Bellour, 1995). These processes can be expected to be particularly prevalent in religious groups, where members deviating from the dominant orthodoxy often will be judged as heretics and apostates and, hence, will be punished and ostracised (Putra, Mashuri, \& Zaduqisti, 2015). The same is true for imposters or infiltrators who are not perceived as rightful members of a group. They are treated similarly as they are believed to threaten the group's entitativity and unity (e.g. Hornsey \& Jetten, 2003).

Collective manifestations are political by virtue of their societal emergence and impact and it is no secret that more often than not political goals are reached by smear campaigns that are intended to fuel prejudice and motivate people's participation. However, in many societies, the explicit expression of prejudice is discouraged (Augoustinos \& Every, 2007), which may lead to reframing one's prejudice in an implicit and hidden way (Durrheim, 2012). Still it serves the same function as classic prejudice: To express a negative feeling and contempt against persons based on their group membership and to justify discrimination. Using a seemingly objective pretext by attributing a person disdain of central values may justify discriminatory action and open contempt can be a tool to deny any prejudice or racist issue in politics. Finding a plausible reason for discrimination, so the conclusion, helps to avoid moral sanctions and to hide self-interest even in black campaigning (Augoustinos \& Every, 2010). In many cases such campaigns have racist undertones (van Dijk, 1992). While the patterns and reasons invented as a pretext may differ widely between countries and political parties, contenders in highly religious countries are likely to use religious misdemeanours as a socially acceptable way to camouflage religious and racist hatred against a political opponent.

In Indonesia, Putra (2016) showed that hate speech delivered by a prominent Muslim figure in a mosque targeting Ahok, the non-Muslim Chinese gubernatorial candidate of the 2012 Jakarta election, could deflect being charged of hateful racism by appealing to him only delivering 'Allah's words'. Given the deeply religious identities of the Sunni Muslim majority, such an argument works well in Indonesia: Religious people are seen as 'good people', whereas non-religious people are vilified. Such religiously dressed up justifications are regularly being used to attack political opponents in Indonesia and it was used in the case of the present study where a manipulated voice recording of a speech was used to incriminate the politician Ahok of blasphemy. 


\section{Overview of the Present Study}

We analyze the interlinking of social identity and religion and its implications for social peace and political freedom in a society. We study how participants of a political rally in Jakarta, Indonesia represent the event, which initially was a peaceful rally that turned violent later. In particular, we are interested in strategies how interviewees attempt to preserve their group's reputation by accusing intruders of triggering the violence.

The study addresses three research questions in a real-life setting: How do protesters perceive the religious, ethnic, and political motives that lead to these protests? How do they cope with the fact that members of their ingroup engaged in violence towards the end of the rally? And how do protesters deal with accusations of the protests being motivated by prejudice towards Chinese and Christian Indonesians?

\section{Method}

\section{Participants}

In total 17 Muslims who had been involved in the November 4 Muslim rally in Jakarta participated in the interviews. One participant refused the interview to be further analysed. This left us with 16 participants, ages ranging from 17 to 48 years old. Three participants left the rally before 18.00 whereas 13 stayed until after 18.00 when the riots occurred. Ten participants were males and six females.

\section{Material and Procedure}

The interviews took place 51 days after the November 4 Muslim rally between December 7, 2016 and January 26, 2017. A snowball technique was used to invite potential interviewees: Respondents were selected on the basis of their involvement in the November 4 Muslim rally and they were asked in turn if they can help us to find other subjects. Before the interviews, the participants were asked to fill informed consent forms informing them that participation in the interview is voluntary and that participants were free to withdraw from the study at any time without penalty. Extracts from interviewees' statements were marked with ' $F$ ' for female, ' $M$ ' for male, age, and ' $<18$ ' versus ' $>18$ ' for participants who left the rally before the outbreak of violence at 18.00 or who stayed there also after 18.00 and witnessed the violence.

All interviews were conducted in Bahasa Indonesia language. Their English translation is listed in the Appendix. Besides these questions, the interviewer elaborated on an issue wherever they found relevant.

In order to elicit responses, we also showed two images of a man suspected as the provocateur in the rally and two videos: 1) showing a statement of one cleric (before he participated in the rally) that if the incumbent Governor expresses his apology, then suing him is not needed; 2) showing an expression of apology from the incumbent Governor.

\section{Analysis}

We used thematic analysis to accumulate meaningful sets of statements (Parker, 2013) around the main research questions as iterated in the introduction (see Overview of the Present Study):

1. How do protesters perceive the religious, ethnic, and political motives that lead to these protests, and how, then do they react by knowing that Ahok has apologized?

2. How do protesters deal with accusations of the protests being motivated by prejudice towards Chinese and Christian Indonesians?

3. How do they cope with the fact that members of their ingroup engaged in violence towards the end of the rally?

Accordingly, we organized the participants' thoughts, metaphors, emotions, and motivations around these three main topics and excluded statements that seemed to be unrelated from further analysis. 
The data were transcribed, so that they could be categorized and managed with other text data. The texts were then identified, categorized into themes, and translated into English. In the first analysis step, two of the present authors selected relevant statements which were related to the three main issues as explained above. These statements where then further analysed as a means of identifying elements of a shared world view or a shared social representation among the participants. Statements that differ from this shared social reality are mentioned as well in the results section.

\section{Findings}

The statements given by the interviewees can be categorized into three themes according to our three research questions:

1. Political intransigence: Ahok has apologized, but legal process must proceed,

2. Deflecting supposed racism: We don't support a non-Muslim candidate, but the rally was not because of racism,

3. Othering the blame: the violent rioters were not part of 'us'.

\section{Political Intransigence}

Before the first rally on October 14 asking Ahok to apologize and to step down, Ahok had already officially apologized for his speech on October 10. We were hence interested to know the opinion of the November 4, 2016 rally demonstrators about Ahok's apology, and why they still demanded during the rally to arraign and to punish Ahok. Of 16 participants, 14 stated that the legal process had to be continued with or without Ahok's apology. Four participants claimed not to have known that Ahok had already apologized.

One of the reasons why the legal process must continue is that an apology is not enough to stop the process. The participants maintain that the law must be enforced so that there is no discrimination.

Interviewer: Ahok already apologized, what is your opinion?

F18<18: Well if someone apologizes, does it mean that he should not be tried?

Interviewer: It depends on your interpretation, what do you think?

F18<18: If after apologizing it means that it is over, the jail will be empty. As an example in the bombing cases ${ }^{3}[. .$.$] , he apologized, he regretted that he was wrong and so forth, if then he was released,$ will he do it again? We don't know, then for example a thief, he apologized and everything is settled but he still continues doing it.

The conversation above explains that forgiveness does not mean that Ahok can escape from the legal process. It also seems that the basic goal for the demonstrators was to put Ahok in jail or at least to bring him to court. This indicates inconsistent statements: In the beginning, they wanted Ahok to apologize. However, when Ahok had apologized, they argued that it was not just about an apology. If Ahok had done wrong - since Indonesia is a state of law - then Ahok must be arraigned and punished. Of this reason, another participant even accused the government of trying to delay Ahok's trial.

F17<18: Well because when it comes to the Islamic scholars, a little bit of mistake and they are imprisoned and have to stand trial like when there was a problem, what was it [...] insulting the President will swiftly be persecuted, but when it comes to him (i.e., Ahok) there is a delay, because we also see the person who claims to be a prophet, getting imprisoned for changing the Quran! This is the same.

3) Since 2000, Indonesia has experience several bombing incidents most of which were conducted by Islamic terrorist groups. 
The participant compares Ahok's case to accusations of hate speech in the aftermath of a speech which was delivered by a prominent Muslim figure in the middle of the 2012 Jakarta election. A Muslim cleric assaulted in a speech one of the candidates because he is a non-Muslim Christian. Nonetheless, he could avoid persecution because he could convince the law enforcement that his statement was a religious sermon. In contrast, even though she did not intend to insult Islam, a member of a minority group who just complained that the call for prayer in the local mosque was too loud could spark collective rage among majority Muslims who were accusing the minority member a blasphemy toward Islam (Bevins, 2018). This incident stimulated some Muslims to attack the minority's house of worship (Tehusijarana \& Gunawan, 2018). There is an asymmetry here regarding how majority members treat ingroup members and how they treat outgroup members. In other words, majority members tend to favour the group they belong to and to derogate the group they do not belong to (Tajfel, 1982).

Additionally, four of the 16 participants stated that they did not know that Ahok had apologized and such apology was considered to come too late.

Interviewer: Ahok apologized on October 10, so it was prior to the demonstrations, did you know that?

M20>18: No, not yet.

Interviewer: [...] Yes he had already apologized. We also have several videos (as evidence). [...].

M20>18: Well that's good. I did not know before. It's good when there is an intention to apologize, but, the Islamic crowd was already provoked by the broadcasts, so it did not reach the whole community, including me who didn't know.

If we look at the conversation above, it seems as if the participants hold ambiguous feelings (i.e. double meaning) towards Ahok's apology, they were happy with it yet it apparently came too late since the movement had already begun as a reaction to a blasphemous provocation.

\section{Deflecting Supposed Racism}

There was a statement by the demonstrators saying that they were accusing Ahok not because he is a non-Muslim or because he is a Chinese non-Muslim, but rather because Ahok had tarnished Islam. We asked the participants what their opinion towards Ahok would be like, if the blasphemy issue had not happened. Would they have supported Ahok or not? Most of the participants responded that they would not have voted for Ahok, anyway.

Interviewer: Okay, if at that time Ahok had not mentioned Al-Maidah [the Quranic verse], would you support Ahok?

F17<18: No.

Interviewer: Why?

F17<18: Because we were told (by Allah), by what's his name, choosing a kafir leader, that is what's being questioned .... Yea, scared of being wrong or whatever so, like that, so there were those two problems.

In fact, the interviewees questioned the reasons for Ahok's reference to the Quranic verse:

Interviewer: In his speech in Thousand Islands [a region in Jakarta] Ahok related his experience from Bangka Belitung during an earlier campaign [when he was running for regent] when the opposition parties had used the verse of Al-Maidah to lure away the voters. The story told to the voters' meeting in the Thousand Island region, hence was: 'If you feel you cannot vote for me, because the opponents use the verse Al-Maidah mendaciousy, it's okay!' In fact, then the charge of blasphemy [during his visit to 
Thousand Islands] is based on Ahok's telling a story of what had happened in another campaign; what do you think? [...]

F17<18: Well [...] In my opinion, why did he have to bring up the Quran since he is a Christian?

In the conversation above, F17<18 did not support Ahok because of his background. Her dislike increased when she knew Ahok brought up a Quranic verse in his speech, as it is considered improper for a non-Muslim to speak about a Quranic verse.

Interestingly, this contradicts a finding according to which in conflicts about sacred values compromise becomes more likely if one side steps back a bit in their sacred beliefs (Ginges, Atran, Medin, \& Shikaki, 2007), which could have been Ahok's apology. In this case the demonstrators' hatred and resistance against the non-Muslim, however, prevailed over rational deliberation:

F17<18: [...] We also want to see the person who claims to be a prophet [Ahok], getting imprisoned for changing the Quran!

Another participant, F18<18, shared her dislike of Ahok because he thought that Ahok propagates ideas that are harmful to Indonesian society:

Interviewer: Here I want to know your opinion about Ahok, [...] if Ahok was not stuck with the verse al-Maidah, would you support Ahok?

F18<18: No!

Interviewer: Why?

F18<18: The reason is because of the religious command, secondly I don't want to support a person that allows adolescents free sex as long as condoms are used, I don't want to. I also don't want a leader who allows liquor as long as the beer and the wine are considered good. I also don't want a leader that makes apartments for prostitution; [...] he said rather than on the street it is better if they are concentrated somewhere, and I don't want that.

Interviewer: Which one of those three things you mentioned that is already applied?

F18<18: So as for the apartment I think it's being built, planned or soon I don't know because after which I'm too lazy to find out about Ahok [...] so if that is possible at the end it will happen. You may see [...] how he thinks and he also allows alcohol because he thinks that it is not dangerous whereas I think that with a drunk person anything can happen.

In the conversation above, F18<18 is shown to have prejudice about Ahok. Because of her hatred, she did not want to clarify the issues she brought up. Her reasoning seems to solely depend on her instinct that Ahok is wicked. In Indonesian culture, the issue of free sex commonly leads to negative perceptions and individuals who support free sex and alcohol are considered as morally wrong. For Muslims, pre-marital sex is forbidden and radical Muslims may even demand perpetrators to be punished by stoning as described in the Quran. Up until now, there is no legal prostitution in Indonesia. Alcoholic beverages are forbidden for Muslims and can only be obtained in specific areas.

Taken together, the participants' statement that they opposed Ahok not because he is a non-Muslim or because he is a Chinese non-Muslim, but rather because of moral misconduct is a case of denying one's racial prejudice. One of the reasons why the participants may be motivated to deny their prejudice can be that they do not want to be labelled as 'racist Muslims'. In Indonesia, such a label is perceived as highly negative (Putra, 2016). 


\section{Othering the Blame}

The tagline of the rally on November 04, 2016 was "Peaceful Muslim Action in defending Islam" (Amelia, 2016). Nonetheless, after $18.00 \mathrm{~h}$ a riot occurred, leading to speculations and denials. Only a small number of participants $(n=2)$ stated that the leaders of the violently 'derailed' rally need to apologize.

Interviewer: There was a riot during the 411 (i.e. November 4 rally), in your opinion does the Islamic community or the leader of the action need to apologize for the riot?

F18<18: In my opinion the one who did the damage, [...] must apologize, that is the one [who started the riot] suspected of being from HMI [Himpunan Mahasiswa Islam/Islamic Student Association]. They [an HMI representative] confirmed and apologized for what had happened [if it was truly an HMI member]. [...]

Interviewer:: [...] Should the top leaders apologize?

F18<18: The top leaders should apologize. Like Habib Rizieq, at least he would be remembered as not being aggressive [...].

In the beginning of the conversation, F18 $<18$ argued that the ones who need to apologize are those who were involved in the riot. However, when we asked whether the leaders of the rally need to apologize as well, she argued that the leaders need to apologize so that emotional tensions can at least be reduced. Rizieq is a leader of FPI (see Woodward et al., 2014), a mass Islamic group known for their aggressive persecution of minority religious groups (e.g. Ahmadiyya group) and other individuals which they think have violated Islamic law (e.g. procuration of women, gambling, selling alcohol).

Another participant thought that Muslims need to apologize when they violate the law:

Interviewer: There was a riot during the action, in your opinion do the Islamic community or the ulama (i.e. Islamic cleric) involved need to apologize or not for the riot?

M17>18: They already apologized.

Interviewer: Oh, I didn't know, how did they apologize?

M17>18: Well, I don't know yet, if I'm not mistaken they already apologized from what I heard, if I'm not mistaken.

Interviewer: Who, Habib Rizieq?

M17> 18: Yes, as the head of GNPF (Gerakan National Pengawal Fatwa/National Movement of 'Fatwa' Guard) also apologized for the riot, seems like it, that's what I heard.

Interviewer: Should they apologize, in your opinion?

M17>18: Yes, apology is needed

Interviewer: How?

M17>18: In my opinion they should apologize because they violated the law.

Interviewer: An apology for November 04?

M17>18: Yes.

In the beginning of the conversation, M17>18 believed that Muslim leaders had already apologized for what happened at the night of November 04. For him, it was important for Muslims to apologize as Muslims need to abide by the law. 
The majority of interviewees $(n=12)$ said that apology was not needed or regarded the ones involved in the riots either as ingroup deviants, that is 'black sheep' or as intruders who cannot be considered to represent the demonstrators, so apology was not needed.

Interviewer: [...] Who do you think the riot started?

M19<18: It was probably intruders from other mass organizations [...] non-Muslims.

Interviewer: Is it possible that it was the Islamic side or the Muslims who started the riot?

M19<18: No.

Interviewer: Not possible? How do you know?

M19<18: Not possible. [...] Because from the beginning it felt so peaceful [...] so how could there be a riot.

In the conversation above, M19<18 believes that the Muslim collective action was infiltrated by outsiders who provoked the demonstrators. To him, the rally was peaceful. In other words, the participant blamed other groups for intruding the Muslim rally and provoking the clash. Because the interviewees wanted to represent peace as the core value of Islam, they deny that the demonstrators, who provoked the violence, were a part of them. Other participants supported this argument:

F17<18: [...] Intruders were not from the demonstrators, don't know from which organization, and there were some who were arrested using the same uniform, they were Catholics, on their identity card $[\ldots]$.

Interviewer: Are you sure? [...]

F17<18: There is a picture I got showing the provocateur.

Interviewer: Where did you get it from?

F17<18: Our friends' Whatsapp (i.e. social media) group in religion, the alumni there are a religious association.

Interviewer: Did you believe from the beginning that there will be intruders?

F18<18: I believed so, because that many people were not recorded and it can happen like the 411 case there was an intruder who wanted to shoot Habib Rizieq but was prevented to do so [...] after that, I heard that the person who died was a Christian on his identity card, so all of this happened because it was not recorded [...] everyone was free to join.

The interviewers also showed a picture of a man suspected of being a provocateur in the rally to the participants. His stature is typical for people coming from the eastern region of Indonesia, who are usually identified as non-Muslim. We traced the background of the picture, and the truth is, that the actual religion of the man is Islam, which was not discernible in the photograph, of course. Most Muslim participants believed that the man in the picture was a provocateur. Charging outgroup members of wrongdoings instead of members of the ingroup is ubiquitous and helps to maintain a positive self-image of Islam as a peaceful religion (Putra, Danamasi, Rufaedah, Arimbi, \& Priyanto, 2017; Yildiz \& Verkuyten, 2013).

Moreover, as was also found in previous studies (Howarth, 2014; Stott, Hutchison, \& Drury, 2001), some participants who joined the November 4 rally also blamed the police for starting the riots:

M21>18: Because when I was overseeing it at Kapolda region [...] I saw the officers three times, changing three times. The shift was about three times [...] and the officers did not like that [and 
appeared agitated]. Maybe, [...] because the police might also be tired from observing the crowd, not going back home. But we decided not to go home before this was finished [despite the law that rallies can only be arranged until 18.00].

\section{Interviewer: $\mathrm{Hmm}$.}

$[\ldots]$

M21>18: But the officers, maybe because of impatience, the officers took action, and immediately disbanded the rally.

M21>18: The police started shooting, what do you call it? Tear gas.

Interviewer: Tear gas?

M21>18: Yes, tear gas was everywhere. And maybe others were looking at Habib giving his speech. During his speech [...] some were still calm. Now, in the beginning [...] the commotion started at the front, that is the riot. Habib was still orating. Still orating, still, still yelling 'don't be provoked, don't be provoked'. Now those who were provoked may already be at the front. Don't know where the provoked were from. Now, the fault was, the officers already shot tear gas every where.

This conversation describes police officers as responsible for the violence by shooting tear gas at the demonstrators standing close to the police. Hence, if the interviewees did not blame outside provocateurs for the riot, they revert to seeing the police as the initiators. In any case, most respondents showed an interest in separating the violent wrong-doers from their Muslim ingroup.

\section{Discussion}

Our study shows how Indonesian Muslims justify the rejection of a contender of Chinese origin in an election using a rigged accusation of blasphemy. It becomes clear in the interviews that the accusation of blasphemy serves to camouflage the deep anti-Chinese sentiment of the demonstrators and to deflect the accusation of racism. The interviews also reveal how a violent riot at the end of a manifestation is explained by blaming non-Muslim outgroup members, that is either intruders or the police. All things together demonstrate the power of religious identities in mobilizing and justifying mass action even if violent.

The reproach of a 'religious insult' is a particularly useful tool in political disputes that involve members of a minority that does not share in the majority religion. This follows from the fact that religion is a significant part of identity and present in many aspects of life such as politics, economy, and culture. Other religions are legally tolerated but atheism is forbidden in Indonesia. Religious people, even if not Muslim, are understood as 'good people' whereas unreligious people are judged as vile.

The reproach of blasphemy resulted when a video went viral on social media that had been manipulated by deleting a half-sentence and that made the speaker appear as if he doubted the validity of a Quranic verse. Its popularity evoked protests due to the politician's alleged blasphemy of doubting 'Allah's words'. Clearly, accusations of 'religious insult' and 'blasphemy' are serious issues that easily lead to collective anger and contempt. In Indonesia, this happened not only in the present case, but also in various other occasions against Christians or against the minority Muslim group Ahmadiyya (Putra \& Wagner, 2017).

The Muslim manifestations were advertised and planned as a 'peaceful action' (BBC, 2016a) that later tipped over to a violent riot; that is, a normative collective action became non-normative (Tausch et al., 2011). In the interviews the respondents maintained that Muslim participants would not need to apologize because the perpetrators and provocateurs were supposed to be intruders. They were accused as coming from a different group, which in Indonesia means that they are from a different religion and their alleged goal was seen as derogating the image of Islam. Such denial is well known from a multitude of similar events the world over where outgroup members are blamed to avoid 
social sanctions against the ingroup (e.g. Stott et al., 2001; Augoustinos \& Every, 2007). In the present case it served to avoid black-sheeping (Marques \& Paez, 1994) ingroup Muslims who would have tainted the self-image of Islam as a peaceful religion.

In a similar vein the respondents were eager to deflect accusations of bias and religious racism even though there were ample instances. There was the case of a Muslim cleric who was absolved of the reproach of instigating hatred against the Christian Ahok in court by arguing that his statement was a religious sermon (Putra, 2016). In contrast, even though she did not intend to insult Islam, a woman of the Buddhist minority who complained that the call for prayer in the local mosque was too loud, sparked collective rage among Muslims raising the accusation of blasphemy and a court of justice punishing her (Bevins, 2018). Additionally this motivated some people to attack a temple (Tehusijarana \& Gunawan, 2018). These are examples of the well-known asymmetry in treating one's ingroup members better than the members of the outgroup (Tajfel, 1982). Hence, it is not surprising that many participants demanded that Ahok should be put on trial in spite of his apology.

The racial and religious biases issue and its denial were also prominent in the interviews (van Dijk, 1992). According to Nelson (2013) its denial is a constitutive of racism per se. Accordingly, most of our interviewees claimed that the rally was not because of prejudice against a certain group, but because the attacked contender had insulted Islam and the rally was meant to bring him to court. However, when asked whether they would have supported the Chinese politician if he had not been accused of insulting Islam, the clear response was that their rejection was because him not being Muslim.

Like in most countries, also in Indonesia showing outright prejudice is judged negatively and seen as an expression of ignorance and impoliteness (e.g. Billig, 2001). This undesirable behaviour, of course, had to be hidden by the pretext of blasphemy that comes in handy in deeply religious cultures (Putra, 2016). In more secular societies like Greece, for example, the Golden Dawn Party's agenda to expel immigrants from Greece (Kadianaki \& Andreouli, 2017) justifies its open racism by blaming immigrants for the collapse of the 'native Greek' economy.

The socially and psychologically 'deep' complex of political behaviours and their disguises is often bound to affectively laden identities where collective action is easily fuelled by allusions to sacred values (Ginges et al., 2007), be it questioning some god's 'words' or the supposed purity of Greeks. In any case this complex is an important issue in contemporary societies that needs more studies in real life conditions for finding ways out of conflictual intergroup relations.

Funding: The authors have no funding to report.

Competing Interests: The authors have declared that no competing interests exist.

Acknowledgments: We thank M. Faisal Magrie \& Reisa S. Arimbi for their countribution in the very early work of the paper and helping to conduct interviews.

\section{References}

Amelia, R. M. (2016, November 7). Kronologi demo 4 november: Dari damai hingga berakhir ricuh. detikNews. Retrieved from https://news.detik.com/berita/d-3339694/kronologi-demo-4-november-dari-damai-hingga-berakhir-ricuh

Augoustinos, M., \& Every, D. (2007). The language of 'race' and prejudice: A discourse of denial, reason, and liberal-practical politics. fournal of Language and Social Psychology, 26, 123-141. https://doi.org/10.1177/0261927X07300075

Augoustinos, M., \& Every, D. (2010). Accusations and denials of racism: Managing moral accountability in public discourse. Discourse \& Society, 21, 251-256. https://doi.org/10.1177/0957926509360650

Batel, S., \& Castro, P. (2015). Collective action and social change: Examining the role of representation in the communication between protesters and third-party members. fournal of Community \& Applied Social Psychology, 25, 249-263.

https://doi.org/10.1002/casp.2214 
Batubara, H. (2016, October 7). Ini video utuh Ahok pidato singgung surat Al-Maidah 51 yang jadi polemik. detikNews. Retrieved from https://news.detik.com/berita/3315258/ini-video-utuh-ahok-pidato-singgung-surat-al-maidah-51-yang-jadi-polemik

BBC. (2016a, November 4). Indonesia protest: Jakarta anti-governor rally turns violent. BBC News. Retrieved from http://www.bbc.com/news/world-asia-37856476

BBC. (2016b, November 16). 'Ahok': Police name Jakarta governor as blasphemy suspect. BBC News. Retrieved from http://www.bbc.com/news/world-asia-37996350

Becker, J. C., Tausch, N., Spears, R., \& Christ, O. (2011). Committed dis(s)idents: Participation in radical collective action fosters disidentification with the broader in-group but enhances political identification. Personality and Social Psychology Bulletin, 37, 1104-1116. https://doi.org/10.1177/0146167211407076

Betrand, J. (2004). Nationalism and ethnic conflict in Indonesia. Cambridge, United Kingdom: Cambridge University Press.

Bevins, V. (2018, August 23). Woman's blasphemy conviction in Indonesia sparks backlash, intensifies concerns. The Washington Post. Retrieved from https:/www.washingtonpost.com/world/2018/08/23/womans-blasphemy-conviction-indonesia-sparks-backlash-intensifiesconcerns

Billig, M. (2001). Humour and hatred: The racist jokes of the Ku Klux Klan. Discourse \& Society, 12, 267-289. https://doi.org/10.1177/0957926501012003001

Breakwell, G. M. (2015). Identity process theory. In G. Sammut, E. Andreouli, G. Gaskell, \& J. Valsiner (Eds.), The Cambridge handbook of social representations (pp. 250-267). Cambridge, United Kingdom: Cambridge University Press.

Brown, A., Abernethy, A., Gorsuch, R., \& Dueck, A. C. (2010). Sacred violations, perceptions of injustice, and anger in Muslims. Journal of Applied Social Psychology, 40, 1003-1027. https://doi.org/10.1111/j.1559-1816.2010.00608.x

Cochrane, J. (2017, May 23). Governor of Jakarta withdraws appeal of blasphemy sentence. The New York Times. Retrieved from https://www.nytimes.com/2017/05/23/world/asia/indonesia-ahok-blasphemy-appeal.html

Deaux, K. (1996). Social identification. In E. T. Higgins \& A. W. Kruglanski (Eds.), Social psychology: Handbook of basic principles (pp. 777-798). New York, NY, USA: Guilford Press.

Drury, J., \& Reicher, S. (2000). Collective action and psychological change: The emergence of new social identities. British fournal of Social Psychology, 39, 579-604. https://doi.org/10.1348/014466600164642

Drury, J., \& Reicher, S. (2005). Explaining enduring empowerment: A comparative study of collective action and psychological outcomes. European fournal of Social Psychology, 35, 35-58. https://doi.org/10.1002/ejsp.231

Durrheim, K. (2012). Implicit prejudice in mind and interaction. In J. Dixon \& M. Levine (Eds.), Beyond prejudice: Extending the social psychology of conflict, inequality and social change (pp. 179-199). Cambridge, United Kingdom: Cambridge University Press.

Effendy, B. (2003). Islam and the state in Indonesia. Singapore: Institute of Southeast Asian Studies.

Ginges, J., \& Atran, S. (2014). Sacred values and cultural conflict. In M. J. Gelfand, C. Chiu, \& Y. Hong (Eds.), Advances in culture and psychology (pp. 273-301). New York, NY, USA: Oxford University Press.

Ginges, J., Atran, S., Medin, D., \& Shikaki, K. (2007). Sacred bounds on rational resolution of violent political conflict. Proceedings of the National Academy of Sciences of the United States of America, 104(18), 7357-7360. https://doi.org/10.1073/pnas.0701768104

Holtz, P., \& Wagner, W. (2012). Dehumanization, infrahumanization, and naturalization. In D. J. Christie (Ed.), The encyclopedia of peace psychology. Malden, MA, USA: Wiley-Blackwell.

Hornsey, M. J., \& Jetten, J. (2003). Not being what you claim to be: Impostors as sources of group threat. European fournal of Social Psychology, 33, 639-657. https://doi.org/10.1002/ejsp.176

Hosen, N. (2005). Religion and the Indonesian constitution: A recent debate. fournal of Southeast Asian Studies, 36, 419-440. https://doi.org/10.1017/S0022463405000238

Howarth, C. (2014). Connecting social representation, identity and ideology: Reflections on a London "riot”. Papers on Social Representations, 23, 4.1-4.30. Retrieved from http://psr.iscte-iul.pt/index.php/PSR/article/view/294

Kadianaki, I., \& Andreouli, E. (2017). Essentialism in social representations of citizenship: An analysis of Greeks' and migrants' discourse. Political Psychology, 38, 833-848. https://doi.org/10.1111/pops.12271

Kapoor, K., \& Jensen, F. (2016, October 14). Hardline Muslim groups protest over Jakarta's ethnic Chinese governor. Reuters. Retrieved from

http://uk.reuters.com/article/uk-indonesia-protest/hardline-muslim-groups-protest-over-jakartas-ethnic-chinese-governoridUKKBN12E0PA 
Kholid, I. (2016, October 6). Sejumlah Pengacara Polisikan Ahok Gara-gara Kutip Surat Al Maidah. detikNews. Retrieved from http://news.detik.com/berita/3315063/sejumlah-pengacara-polisikan-ahok-gara-gara-kutip-surat-al-maidah? _ga $=1.54446824 .1784916291 .1453026411$

Lamb, K. (2017, May 9). Jakarta governor Ahok sentenced to two years in prison for blasphemy. The Guardian. Retrieved from https:/www.theguardian.com/world/2017/may/09/jakarta-governor-ahok-found-guilty-of-blasphemy-jailed-for-two-years

Leyens, J.-P., Paladino, P. M., Rodriguez-Torres, R., Vaes, J., Demoulin, S., Rodriguez-Perez, A., \& Gaunt, R. (2000). The emotional side of prejudice: The attribution of secondary emotions to ingroups and outgroups. Personality and Social Psychology Review, 4, 186-197. https://doi.org/10.1207/S15327957PSPR0402_06

Marques, J. M., \& Paez, D. (1994). The 'Black sheep effect': Social categorization, rejection of ingroup deviates, and perception of group variability. European Review of Social Psychology, 5, 37-68. https://doi.org/10.1080/14792779543000011

Moscovici, S. (1988). Notes towards a description of social representations. European fournal of Social Psychology, 18, 211-250. https://doi.org/10.1002/ejsp.2420180303

Moscovici, S. (2008). Psychoanalysis: Its image and its public (D. Macey, Trans.). Cambridge, MA, USA: Polity Press. (Original work published 1961)

Nelson, J. K. (2013). Denial of racism and its implications for local action. Discourse \& Society, 24, 89-109. https://doi.org/10.1177/0957926512463635

Parker, I. (2013). Discourse analysis: Dimensions of critique in psychology. Qualitative Research in Psychology, 10, $223-239$. https://doi.org/10.1080/14780887.2012.741509

Pettersson, K. (2019). "Freedom of speech requires actions": Exploring the discourse of politicians convicted of hate-speech against Muslims. European fournal of Social Psychology, 49, 938-952. https://doi.org/10.1002/ejsp.2577

Putra, I. E. (2016). Representations and discourse about religion and Chinese descendants in 2012 Jakarta's election. Qualitative Report, 21, 1799-1816.

Putra, I. E., Danamasi, D. O., Rufaedah, A., Arimbi, R. S., \& Priyanto, S. (2017). Tackling Islamic terrorism and radicalism in Indonesia by increasing the sense of humanity and friendship. In B. Cook (Ed.), Examining global peacemaking in the digital age (pp. 94-114). Hershey, PA, USA: IGI Global.

Putra, I. E., Mashuri, A., \& Zaduqisti, E. (2015). Demonising the victim: Seeking the answer for how a group as the violent victim is blamed. Psychology and Developing Societies, 27(1), 31-57. https://doi.org/10.1177/0971333614564741

Putra, I. E., \& Wagner, W. (2017). Prejudice in interreligious context: The role of metaprejudice and majority-minority status. fournal of Community \& Applied Social Psychology, 27, 226-239. https://doi.org/10.1002/casp.2305

Putra, I. E., Wagner, W., Rufaedah, A., \& Holtz, P. (2019). Identity, representations, religion, and apologizing for past wrongdoings: Muslim discourse about Indonesia's 1965-66 massacres of communists. fournal of Community \& Applied Social Psychology, 29, 492-503. https://doi.org/10.1002/casp.2419

Quiano, K., \& Griffiths, J. (2016, December 2). Indonesia: 200,000 protest Christian governor of Jakarta. CNN World. Retrieved from http://edition.cnn.com/2016/12/02/asia/jakarta-indonesia-protest-ahok/index.html

Reicher, S. D. (1996). "The Battle of Westminster”: Developing the social identity model of crowd behaviour in order to explain the initiation and development of collective conflict. European fournal of Social Psychology, 26, 115-134. https://doi.org/10.1002/(SICI)1099-0992(199601)26:1<115::AID-EJSP740>3.0.CO;2-Z

Sen, R., \& Wagner, W. (2009). Cultural mechanics of fundamentalism: Religion as ideology, divided identities and violence in postGandhi India. Culture and Psychology, 15, 299-326. https://doi.org/10.1177/1354067X09337869

Sheikh, H., Ginges, J., Coman, A., \& Atran, S. (2012). Religion, group threat and sacred values. Fudgment and Decision Making, 7, 110-118. http://journal.sjdm.org/12/12305/jdm12305.pdf

Steenbrink, K. A. (1999). The Pancasila ideology and an Indonesian Muslim theology of religions. In J. Waardenburg (Ed.), Muslim perceptions of other religions: A historical survey (pp. 280-296). Oxford, United Kingdom: Oxford University Press.

Stott, C., \& Drury, J. (2000). Crowds, context and identity: Dynamic categorization processes in the 'poll tax riot'. Human Relations, 53, 247-273. https://doi.org/10.1177/a010563

Stott, C., Hutchison, P., \& Drury, J. (2001). 'Hooligans' abroad? Inter-group dynamics, social identity and participation in collective 'disorder' at the 1998 World Cup Finals. British fournal of Social Psychology, 40(3), 359-384.

https://doi.org/10.1348/014466601164876 
Stott, C., \& Reicher, S. (1998a). Crowd action as intergroup process: Introducing the police perspective. European fournal of Social Psychology, 28, 509-529. https://doi.org/10.1002/(SICI)1099-0992(199807/08)28:4<509::AID-EJSP877>3.0.CO;2-C

Stott, C., \& Reicher, S. (1998b). How conflict escalates: The inter-group dynamics of collective football crowd 'violence'. Sociology, 32, 353-377. https://doi.org/10.1177/0038038598032002007

Tajfel, H. (1978). Differentiation between social groups: Studies in the social psychology of intergroup relations. London, United Kingdom: Academic Press.

Tajfel, H. (1982). Social psychology of intergroup relations. Annual Review of Psychology, 33, 1-39. https://doi.org/10.1146/annurev.ps.33.020182.000245

Tausch, N., Becker, J. C., Spears, R., Christ, O., Saab, R., Singh, P., \& Siddiqui, R. N. (2011). Explaining radical group behavior: Developing emotion and efficacy routes to normative and nonnormative collective action. fournal of Personality and Social Psychology, 101, 129-148. https://doi.org/10.1037/a0022728

Tehusijarana, K. M., \& Gunawan, A. (2018, August 23). The Meiliana case: How a noise complaint resulted in an 18-month jail sentence. The fakarta Post. Retrieved from http://www.thejakartapost.com/news/2018/08/23/the-meiliana-case-how-a-noise-complaint-resulted-in-an-18-month-jailsentence.html

van Dijk, T. A. (1992). Discourse and the denial of racism. Discourse \& Society, 3, 87-118. https://doi.org/10.1177/0957926592003001005 van Zomeren, M., Spears, R., Fischer, A. H., \& Leach, C. W. (2004). Put your money where your mouth is! Explaining collective action tendencies through group-based anger and group efficacy. Fournal of Personality and Social Psychology, 87, 649-664. https://doi.org/10.1037/0022-3514.87.5.649

Vestergren, S., Drury, J., \& Hammar Chiriac, E. (2019). How participation in collective action changes relationships, behaviours, and beliefs: An interview study of the role of inter- and intragroup processes. Fournal of Social and Political Psychology, 7, 76-99. https://doi.org/10.5964/jspp.v7i1.903

Wagner, W. (2017). Embodied social representation. Journal for the Theory of Social Behaviour, 47, 25-31. https://doi.org/10.1111/jtsb.12113

Wagner, W. (2020). Groups in contact: Meta-representations, interobjectivity, and cultural incompatibilities. Fournal for the Theory of Social Behaviour. Advance online publication. https://doi.org/10.1111/jtsb.12259

Wagner, W., Mecha, A., \& Carvalho, M. (2008). Discourse and representation in the construction of witchcraft. In T. Sugiman, K. J. Gergen, W. Wagner, \& Y. Yamada (Eds.), Meaning in action: Construction, narratives, and representations (pp. 37-48). Tokyo, Japan: Springer.

White, M. H., \& Crandall, C. S. (2017). Freedom of racist speech: Ego and expressive threats. fournal of Personality and Social Psychology, 113, 413-429. https://doi.org/10.1037/pspi0000095

Wijaya, C. A. (2016, October 10). Ahok apologizes to Muslims for alleged defamation. The fakarta Post. Retrieved from http:/www.thejakartapost.com/news/2016/10/10/ahok-apologizes-to-muslims-for-alleged-defamation.html

Woodward, M., Yahya, M., Rohmaniyah, I., Coleman, D. M., Lundry, C., \& Amin, A. (2014). The Islamic Defenders Front: Demonization, violence and the state in Indonesia. Contemporary Islam, 8(2), 153-171. https://doi.org/10.1007/s11562-013-0288-1

Wright, J. D., \& Young, J. R. (2017). Implications of religious identity salience, religious involvement, and religious commitment on aggression. Identity, 17, 55-68. https://doi.org/10.1080/15283488.2017.1303382

Yildiz, A. A., \& Verkuyten, M. (2013). 'We are not terrorists': Turkish Muslim organizations and the construction of a moral identity. Ethnicities, 13(3), 359-381. https://doi.org/10.1177/1468796812451219

Yzerbyt, V. Y., Leyens, J.-P., \& Bellour, F. (1995). The ingroup overexclusion effect: Identity concerns in decisions about group membership. European fournal of Social Psychology, 25, 1-16. https://doi.org/10.1002/ejsp.2420250102

Zeromskyte, R., \& Wagner, W. (2019). If your group is (not) great: Positive vs. negative trait priming motivates majorities and minorities to adapt essentialist attributions. Journal of Social and Political Psychology, 7, 478-506.

https://doi.org/10.5964/jspp.v7i1.1018 


\section{Appendix}

\section{List of guiding questions:}

1. Can you explain the reason for your involvement in the demonstration?

2. Is it true that this event had nothing to do with politics? What is the reason?

3. Can you describe the incident that occurred after 18.00? In your opinion, why did the riots occur?

4. Do you believe that there were intruders joining the demonstration from the beginning?

5. Who do you think started the riots?

6. Now on to the ongoing alleged blasphemy case against Ahok: If the blasphemy case is not proven, what should happen with Ahok?

7. Do you believe that Ahok will in fact be brought to court?

8. On the $10^{\text {th }}$ of October, Ahok apologized ${ }^{4}$; what is your opinion? (Video DBS ${ }^{5}$ )

4) To note here, Ahok' apology was also exposed in the online news media, one of those: https://metro.tempo.co/read/811113/ahok-minta-maaf-mui-masalah-hukum-tetap-jalan

5) The interviewees were also shown evidence of Ahok' apology during the interview with Don Bosco Selamun (minutes 05:05): https://www.youtube.com/watch?v=9QFV5ZDJ-Bo\&pbjreload=101 